\title{
Rupture of splenic artery aneurysm in a man with polycythemia vera and acquired von Willebrand syndrome
}

\author{
Nathan L Law, ${ }^{1}$ Fabio A Villada, ${ }^{2}$ Matthew J Kruse ${ }^{2}$
}

${ }^{1}$ Creighton University School of Medicine, Omaha, Nebraska, USA

${ }^{2}$ Radiology, Creighton University School of Medicine, Omaha, Nebraska, USA

\section{Correspondence to} Dr Matthew J Kruse; MatthewKruse@creighton.edu

Accepted 3 June 2021

\section{DESCRIPTION}

A 65 -year-old man experienced sudden onset of abdominal pain while working on his farm without significant trauma. He heard a 'pop' sound, followed by abdominal pain, lightheadedness and diaphoresis. He has a history of polycythemia vera (PV) and chronic severe splenomegaly, treated with roxulitinib. He was diagnosed with acquired von Willebrand syndrome 6 years earlier after prolonged bleeding from a tooth extraction.

On presentation to the local hospital, the patient's symptoms had nearly resolved. He underwent an abdominal CT scan demonstrating a $4.8 \mathrm{~cm}$ splenic artery aneurysm, increased from $1.8 \mathrm{~cm}$ on prior CT 6 years earlier (see figure 1), now with surrounding hemorrhage in the mesentery and lesser peritoneal sac compatible with early rupture (see video 1 ). Hemoglobin was downtrending to $73 \mathrm{~g} / \mathrm{L}$ on immediate transfer to tertiary medical center.

The patient received blood transfusions and von Willebrand concentrate shortly after evaluation. He underwent emergent splenic artery angiogram with coil embolization in the operating room. At the conclusion of this procedure, increased abdominal distention and hypotension were noted. Exploratory laparotomy demonstrated massive hemoperitoneum, and open splenectomy was performed. After a complicated postoperative course, the patient recovered and was discharged home several weeks later.

Splenic artery aneurysms (SAA) are the most common visceral artery aneurysms, with causes including pregnancy/multiparity, hypertension, portal hypertension, connective tissue disease, fibromuscular dysplasia and atherosclerosis. ${ }^{1-3}$ While the

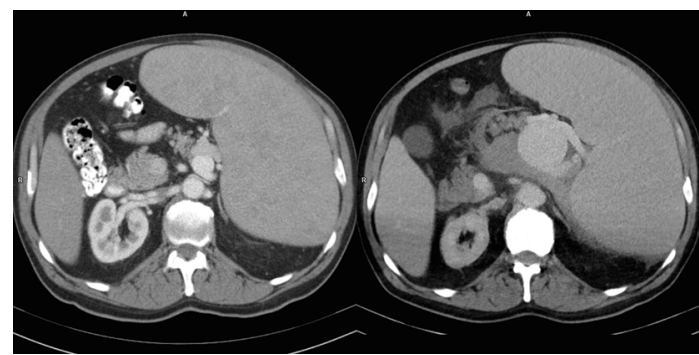

Limited 2021. No commercial re-use. See rights and permissions. Published by BMJ.

To cite: Law NL, Villada FA, Kruse MJ. BMJ Case Rep 2021;14:e243316. doi:10.1136/bcr-2021243316

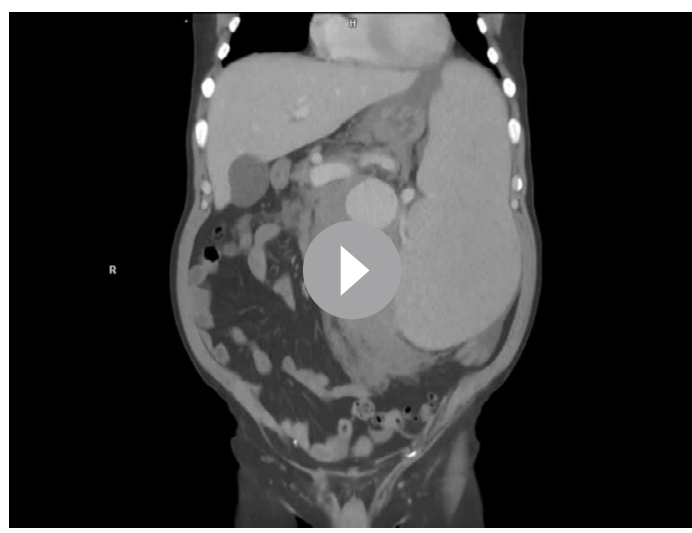

Video 1 Annotated coronal CT images.

vast majority of SAA are asymptomatic, the rupture rate is $2 \%$, with mortality as high as $36 \% .{ }^{1}$ Sudden onset of left upper quadrant pain and hemodynamic instability is a prototypical presentation of rupture. As was a concern in this patient, the 'doublerupture' phenomenon has been described, where patients transiently stabilize (due to tamponade of hemorrhage in the lesser peritoneal sac), followed by subsequent circulatory collapse (when hemorrhage extends to the peritoneal cavity). ${ }^{2}$ Conventional treatment options include surgical excision or ligation, while transcatheter embolization has gained favour. ${ }^{1-3}$ Endovascular therapy should be considered for asymptomatic aneurysms of $2 \mathrm{~cm}$ or larger.

PV is a myeloproliferative neoplasm associated with increased red blood cell mass and splenomegaly. Primary goals of management are to limit the risk of arterial and venous thrombosis using antiplatelet therapy, phlebotomy, interferon therapy or Jak1-2 inhibitors. ${ }^{4}$ Less common hemorrhagic complications have also been described in $\mathrm{PV}^{5}$ related to underlying thrombotic events, antiplatelet medications or acquired von Willebrand syndrome. Although less frequent than with other lymphoproliferative and myeloproliferative neoplasms, acquired von Willebrand syndrome has been described in $12 \%$ of patients with PV, associated with higher platlet counts. ${ }^{6}$ This may predispose to mucosal and cutaneous bleeding, prolonged bleeding after surgical/dental procedures and occasionally major bleeding events.

There is no established association between PV and development of SAA. However portal hypertension is associated with increased risk of SAA (estimated 7\%-20\% prevalence of SAA in cirrhosis ${ }^{3}$ ), 
and up to $13 \%$ of patients with PV may have associated portal hypertension. ${ }^{7}$ Pathogenesis of SAA in portal hypertension may relate to increased splenic blood flow volume, ${ }^{8}$ and similar flowrelated phenomena may have been present in this patient related to his severe splenomegaly.

\section{Patient's perspective}

I was inside a grain bin lifting an auger, and all of the sudden I got dizzy and started sweating. I knew right away something wasn't right. After an hour or two, I felt better, but we still decided to go get checked out. My wife thought I was having a heart attack.

\section{Learning points}

- Although the vast majority of splenic artery aneurysms are asymptomatic, rupture carries a high mortality rate, and preventive treatment of aneurysms $>2 \mathrm{~cm}$ is paramount.

- Acquired von Willebrand syndrome is associated with risk of hemorrhagic complications in polycythemia vera and is seen in patients with higher platelet counts.

- Splenic artery rupture may present with a doublerupture phenomenon, where patients transiently stabilize before worsening hemodynamic status due to increased intraperitoneal haemorrhage.
Contributors All authors were involved in conception of the case. NLL wrote the initial draft of the manuscript and assisted in revising and final approval of the manuscript. FAV and MJK assisted in drafting, revising and final approval of the manuscript. MJK prepared images and obtained informed consent from the patient.

Funding The authors have not declared a specific grant for this research from any funding agency in the public, commercial or not-for-profit sectors.

Competing interests None declared.

Patient consent for publication Not required.

Provenance and peer review Not commissioned; externally peer reviewed.

\section{REFERENCES}

1 Hosn MA, Xu J, Sharafuddin M, et al. Visceral artery aneurysms: decision making and treatment options in the new era of minimally invasive and endovascular surgery. Int J Angiol 2019;28:11-16.

2 Agrawal GA, Johnson PT, Fishman EK. Splenic artery aneurysms and pseudoaneurysms: clinical distinctions and CT appearances. AJR Am J Roentgenol 2007;188:992-9.

3 Madoff DC, Denys A, Wallace MJ, et al. Splenic arterial interventions: anatomy, indications, technical considerations, and potential complications. Radiographics 2005;25 Suppl 1:S191-211.

4 Stein BL, Oh ST, Berenzon D, et al. Polycythemia vera: an appraisal of the biology and management 10 years after the discovery of JAK2 V617F. J Clin Oncol 2015;33:3953-60.

5 Elliott MA, Tefferi A. Thrombosis and haemorrhage in polycythaemia vera and essential thrombocythaemia. Br J Haematol 2005;128:275-90.

6 Mital A, Prejzner W, Świątkowska-Stodulska R, et al. Factors predisposing to acquired von Willebrand syndrome during the course of polycythemia vera - retrospective analysis of 142 consecutive cases. Thromb Res 2015;136:754-7.

7 Toros AB, Gokcay S, Cetin G, et al. Portal hypertension and myeloproliferative neoplasms: a relationship revealed. ISRN Hematol 2013;2013:1-5.

8 Nishida 0, Moriyasu F, Nakamura T, et al. Hemodynamics of splenic artery aneurysm. Gastroenterology 1986;90:1042-6.

Copyright 2021 BMJ Publishing Group. All rights reserved. For permission to reuse any of this content visit https://www.bmj.com/company/products-services/rights-and-licensing/permissions/

BMJ Case Report Fellows may re-use this article for personal use and teaching without any further permission.

Become a Fellow of BMJ Case Reports today and you can:

- Submit as many cases as you like

- Enjoy fast sympathetic peer review and rapid publication of accepted articles

- Access all the published articles

Re-use any of the published material for personal use and teaching without further permission

Customer Service

If you have any further queries about your subscription, please contact our customer services team on +44 (0) 2071111105 or via email at support@bmj.com.

Visit casereports.bmj.com for more articles like this and to become a Fellow 